\title{
Cultivo "in vitro" de tecidos normais e patológicos da cavidade bucal de humanos
}

\author{
Pantelis Varvaki Rados* \\ João Jorge Diniz Barbachan* \\ Manoel Sant'Ana Filho*
}

\section{RESUMO}

Foi realizado o cultivo "in vitro" de fragmentos de mucosa bucal e de lesōes apicais obtidas de humanos com o objetivo de avaliar a aplicabilidade desta técnica como um modelo de estudo. Os resultados obtidos foram de relativo sucesso devido a fatores, tais como: diferenciaçāo tecidual muito grande e problemas de estabilidade dos nutrientes no meio de cultivo empregado.

O cultivo "in vitro" de tecidos patológicos da cavidade bucal permite a possibilidade técnica de se tentar explicar melhor a patogenia de várias lesōes bucais pouco conhecidas ainda e, avaliar melhor formas de tratamento de inúmeras patologias da boca.

Assim sendo, uma primeira tentativa precisava ser feita para testar as várias técnicas de cultivo "in vitro" para a manutenção da vitalidade de tecidos patológicos da boca.

\section{SUMMARY}

The autors presents the results of "in vitro" cultivation of human gengiva and dental abcess with a partial
grade of success.

Acording the autors, failure is related with: the decomposition of the ascorbic acid and the neutralization of sodiun bicarbonate used in the culture mediun. Other problem could be the grade of differentiation of the tissue used in culture.

\section{DESCRITORES}

\section{CULTIVO IN VITRO • GENGIVA • LESŌES APICAIS}

\section{REVISÃO DA LITERATURA}

A técnica de cultivo "in vitro" de tecidos representa para o campo da patologia bucal uma técnica muito promissora, na medida em que cria um modelo experimental capaz de preservar a vitalidade do tecido isolado do resto do organismo e com isso auxiliar o entendimento das reaçōes e etiopatogenia das doenças e permitir o controle de algumas formas de tratamento medicamentoso em lesōes com etiopatogênese incerta $(1,2,7,9$, 11).

Para tanto é necessário inicialmente estabelecer um modelo de cultivo "in vitro" que seja realmente efetivo para a manutençăo da vitalidade de tecidos patológicos da cavidade bucal.

As técnicas de cultivo de tecidos "in vitro" estāo já demonstradas e sāo utilizadas em diversas áreas de estudo, tais como: embriologia $(1,3,4,8)$, citologia
$(5,6)$.

Em cada uma destas áreas existem características particulares, o que torna necessário adaptaçōes destas técnicas para a patologia bucal.

Em 1975, Buchner e Milnek $(1,7)$ testaram a utilizaçāo desta técnica de cultivo "in vitro" para fragmentos de gengiva de humanos obtendo resultados favoráveis inclusive com observaçāo morfológica da proliferaçāo de tecido epitelial dos explantes.

Rados (9) testou a possibilidade de cultivar fragmentos de mucosa bucal, fragmentos de pele e germes dentários de ratos recém nascidos obtendo também sucesso ao final de 7 dias de cultivo.

As técnicas de cultivo "in vitro" podem ser classificadas de acordo com o meio de cultivo a ser empregado:

Meios de cultivo líquidos, próprios para células isoladas ou como meio de trans- porte do tecido desde o local onde é obtido até o laboratório $(1,9)$.

Meios de cultivo semi-sólidos, utiliza-se a associaçāo de um meio sólido Agar/Agar como base de sustentação dos explantes e enriquece-os com meios líquidos, 199, Eagle entre outros, para aumentar os locais de chegada de nutrientes, uma vez que a parte superior do explante é coberta por meio líquido $(10,12,13)$.

Esta técnica de cultivo tem a vantagem de fornecer nutrientes ao explante por todos os lados e, de a princípio năo oferecer limitaçāo quanto ao tempo de manutenção do explante em cultivo $(1,6,8)$.

Cultivo em membrana corio-alantoidea, consiste na preparaçāo destas membranas em ovos de galinha fecundados (24 horas). Após este período se realizam os

* Professor de Patologia Geral e Buco Dental da F.O./UFRGS 
explantes sobre a membrana, que é ricamente vascularizada. Esta técnica tem a vantagem de determinar a circulaçāo sanguínea nos explantes e apresenta o incoveniente de ter um período de tempo de cultivo limitado, de aproximadamente 2 semanas $(1,9)$.

\section{OBJETIVOS}

Este trabalho visa testar uma das técnicas de cultivo "in vitro" de tecidos para a sua aplicabilidade com tecidos obtidos da cavidade bucal de pacientes que foram submetidos a biópsia para confirmar lesőes bucais pré-existentes.

\section{MATERIAL E MÉTODOS}

Foram utilizados 2 casos de lesōes apicais diagnosticados clínica e radiograficamente, e nestes casos durante a intervençāo cirúrgica para remoçāo das lesőes foram removidos fragmentos de mucosa da regiẫo anatômica com objetivo de plastia de tecidos moles. Estes tecidos também foram submetidos a cultivo.

O material obtido das cirurgias era colocado em frascos estéreis contendo meio de cultivo líquido 199 (Interlab Flow) e transportados até o laboratório de patologia da Faculdade de Odontologia da UFRGS. Uma vez no laboratório, estes fragmentos eram removidos do frasco com meio líquido e divididos em duas partes, com aproximadamente $1 \mathrm{~mm}^{3}$, sendo uma parte fixada em formol $10 \%$ a fim de servir como controle e a outra parte transferida para placas de cultivo semi-sólido.

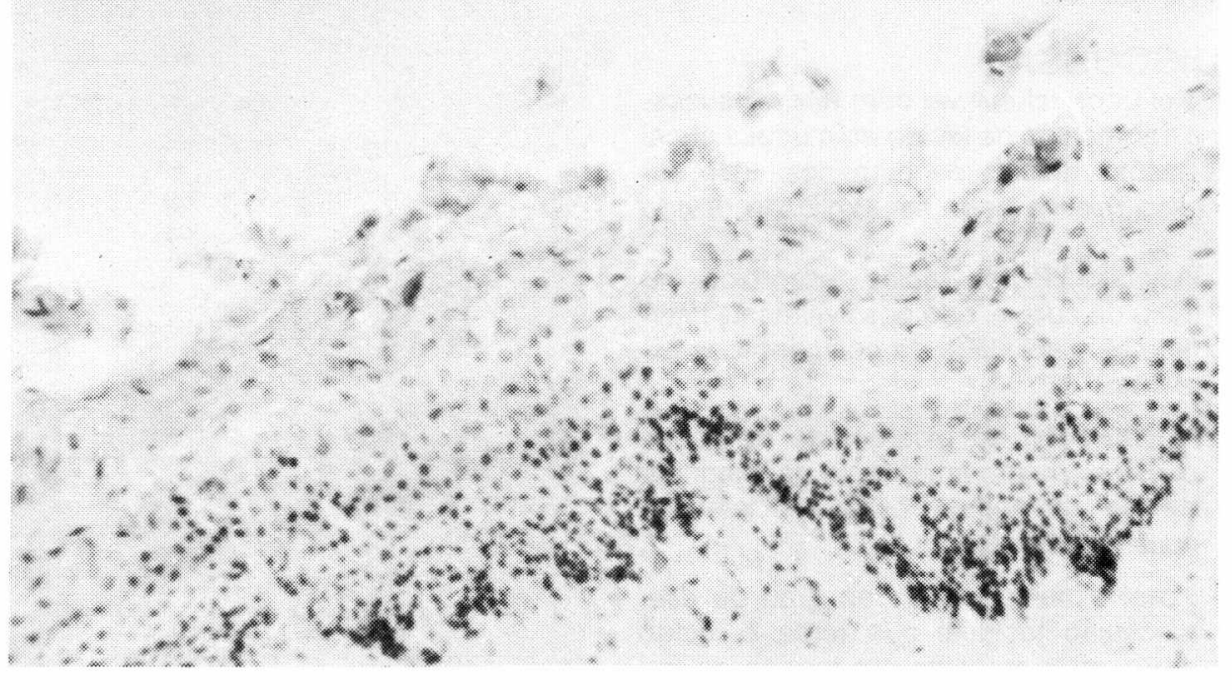

Preparaçăo das placas:

Parte semi-sólida

Agar a $1 \%-5$ partes

Cultivo líquido 199 - 1 parte

(Interlab -Flow)

Extrato embrionário ovino - 1 parte

a) Preparaçăo do Agar

O agar proporciona um substrato semi-sólido para o cultivo de órgāos ou fragmentos de tecidos. O agar é um complexo de polissacarídeos que contém grupos sulfato e carboxila, o que confere a propriedade sinéresi.

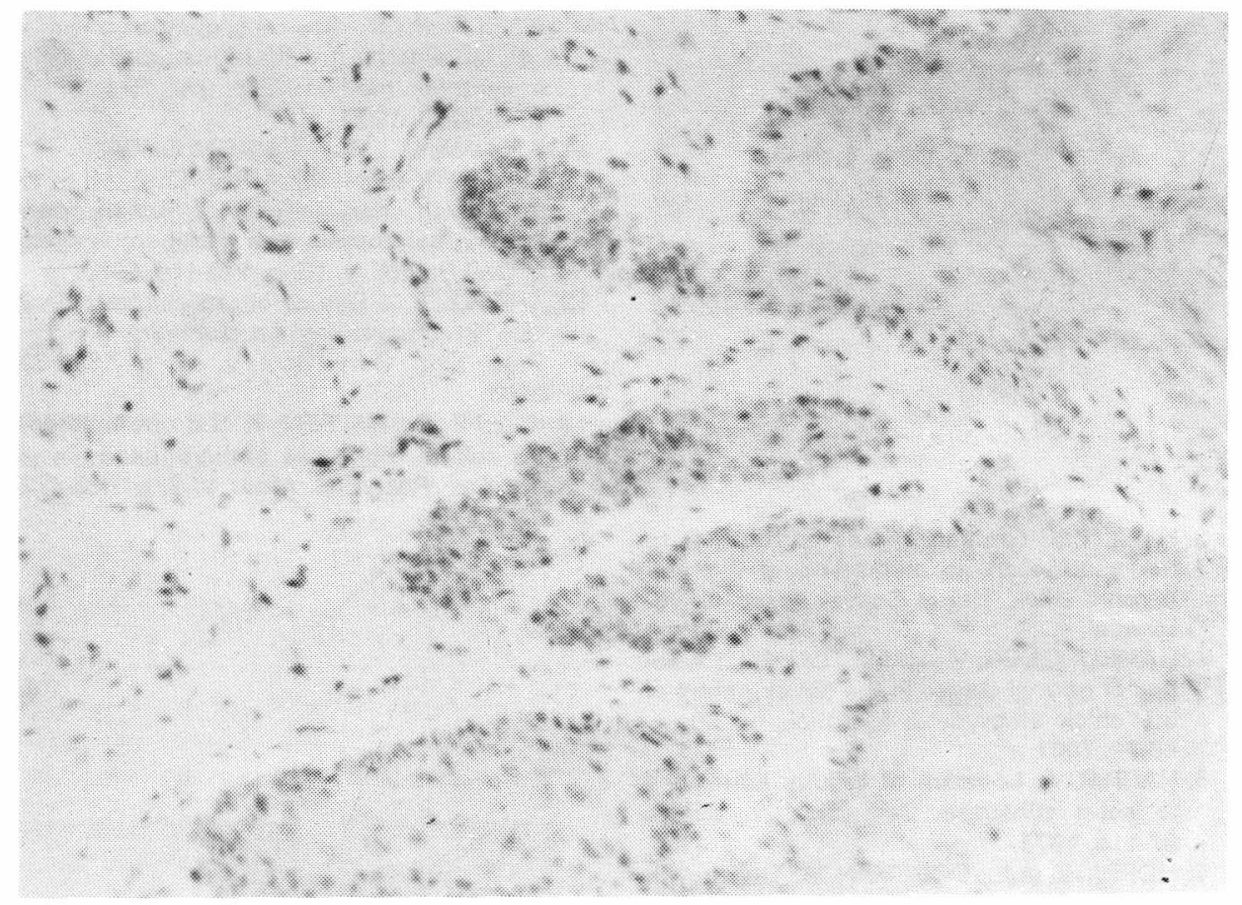

Se dissolve $2.5 \mathrm{~g}$ de agar em $250 \mathrm{ml}$ de líquido de cultivo 199.

Se torna líquido na autoclave por $15 \mathrm{mi}-$ nutos.

Agrega-se o bicarbonato $0.0575 \mathrm{~g}$

Filtra-se com papel filtro e coloca-se em frascos até meia altura e se tampa.

Esterilizaçăo em autoclave por 30 minutos. Deixa-se esfriar e conserva-se em congelador.

Parte líquida

Líquido de cultivo 199, Interlab - Flow.

A parte líquida (Líquido de cultivo 199) dos meios de cultivo era substituída diariamente até o quinto dia, quando constatou-se infecção das placas. Neste dia os explantes foram removidos do cultivo e fixados, seguindo a rotina de processamento para inclusão em parafina, corte e coloração pela Eosina/Hematoxilina.

\section{RESULTADOS}

Os resultados obtidos podem ser avaliados a partir da observaçāo das fotografias 1 e 2 no que diz respeito aos fragmentos de mucosa e nas figuras 3 e 4 para as lesōes periapicais.

Com relação a mucosa bucal, Fig. 1 e 2, pode-se constatar que em comparaçāo com o tecido fixado diretamente ao tecido epitelial da mucosa cultivada perdeu parcialmnente sua estruturaçāo, ausência de céculas queratinizadas e início de desagregaçāo da camada das células basais. O tecido conjuntivo apresenta do ponto de vista morfológico a diminuiçāo discreta do número de núcleos celulares.

No que diz respeito as lesōes apicais Fig. 3 e 4, constatamos que em compa-

\section{R. Fac. Odontol.}


ração à porção de tecido nāo cultivado, o número de células inflamatórias está diminuindo e o estroma colágeno apresenta sinais de desorganização marcada, inclusive com perda de afinidade tintorial pela eosina.

\section{DISCUSSÃO}

Foi possível cultival com relativo sucesso fragmentos de tecido de mucosa bucal e lesōes apicais de humanos. Este sucesso relativo pode ser explicado devido a:

- Instabilidade do ácido ascórbico no meio de cultivo, que possivelmente interferiu na viabilidade do colágeno dos explantes.

- A inativação do bicarbonato de sódio, que é elemento importante na integridade da membrana basal da interface epitélio/mesenquima.

- Possivelmente devido ao grau de diferenciação tecidual que torna o tecido muito mais exigente em termos de nutriçāo.
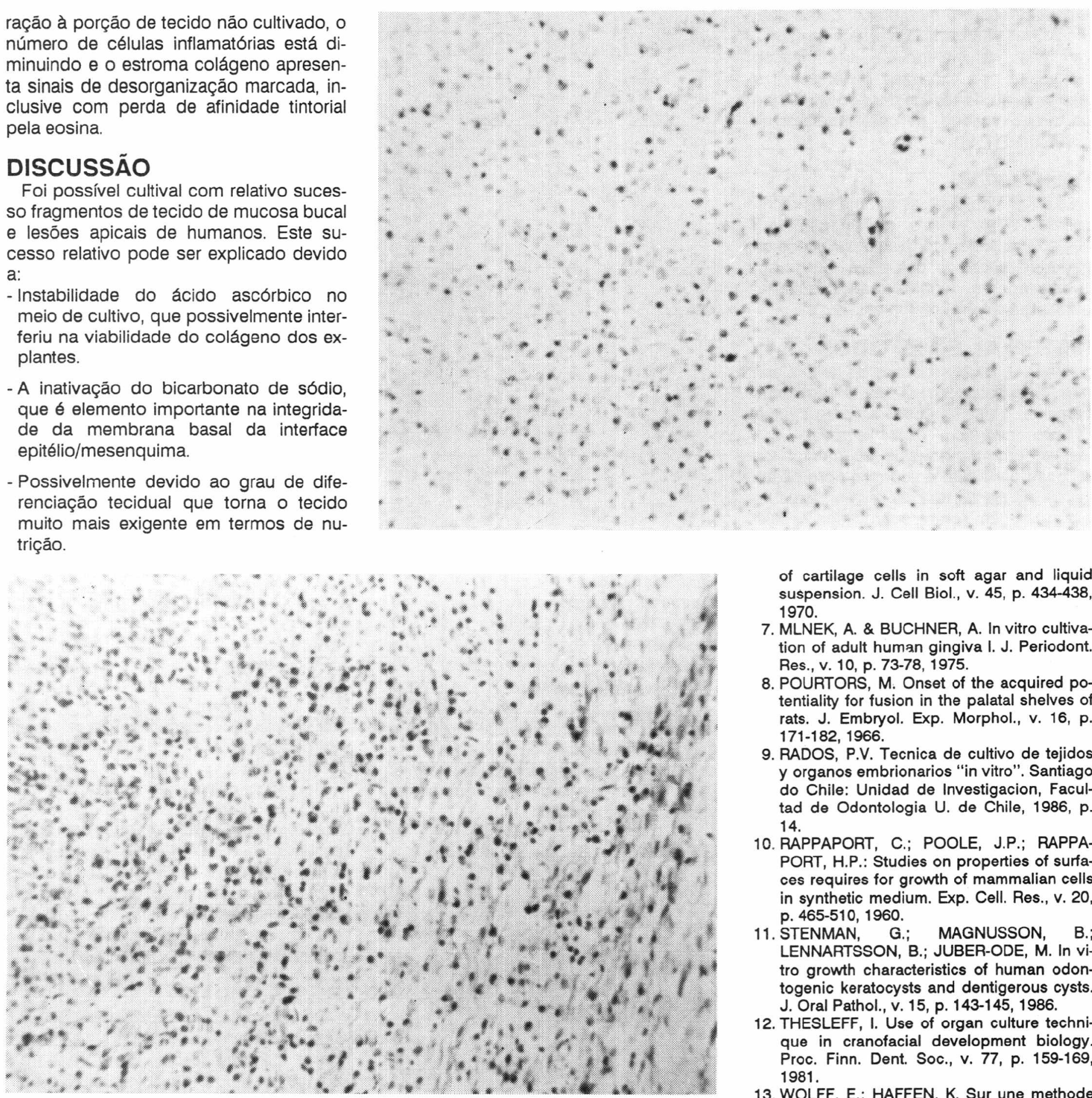

\section{REFERÊNCIAS BIBLIOGRÁFICAS}

1. ACUÑA, J.G. Estudio macro e microscópico del desarrollo del paladar secundario en el raton in vivo e in vitro bajo la accion de Dexametasona. Santiago do Chile: Unidad de Investigacion. Facultad de Odontologia U. de Chile, 1985, p. 33

2. BUCHNER, A.; MLNEK, A. In vitro cultivation of adult human gingiva II. J. Periodont. Res., v. 10, p. 346-356, 1975.
3. HALL, B.K. Grafting organs and tissues to the chorioallantoic membrane of the embryonic chick. Tissue Culture Assoc., 1978. Manual, 4.

4. HAMBURGUER, V.; HAMILTON, H.L.: A series of normal stages in the development of the chick embryo. J. Morphol., v. 88, p. 49-92, 1961.

5. HARRIS, A. Location of cellular adhesions to solid substrata. Dev. Biol., v. $35, \mathrm{p}$. 97-114, 1973.

6. HORWITZ, A.L.; DORFMAN, A. The growth of cartilage cells in soft agar and liquid suspension. J. Cell Biol., v. 45, p. 434-438, 1970.

7. MLNEK, A. \& BUCHNER, A. In vitro cultivation of adult human gingiva I. J. Periodont. Res., v. 10, p. 73-78, 1975.

8. POURTORS, M. Onset of the acquired potentiality for fusion in the palatal shelves of rats. J. Embryol. Exp. Morphol., v. 16, p. 171-182, 1966.

9. RADOS, P.V. Tecnica de cultivo de tejidos y organos embrionarios "in vitro". Santiago do Chile: Unidad de Investigacion, Facultad de Odontologia U. de Chile, 1986, p. 14.

10. RAPPAPORT, C.; POOLE, J.P.; RAPPAPORT, H.P.: Studies on properties of surfaces requires for growth of mammalian cells in synthetic medium. Exp. Cell. Res., v. 20, p. 465-510, 1960.

11. STENMAN, G.; MAGNUSSON, B.; LENNARTSSON, B.; JUBER-ODE, M. In vitro growth characteristics of human odontogenic keratocysts and dentigerous cysts. J. Oral Pathol., v. 15, p. 143-145, 1986.

12. THESLEFF, I. Use of organ culture technique in cranofacial development biology. Proc. Finn. Dent. Soc., v. 77, p. 159-169, 1981.

13. WOLFF, E.; HAFFEN, K. Sur une methode de culture d'organes embryonnaires in vitro. Tex. Rep. Biol. Med., v. 2, p. 463-472, 1952.
R. Fac. Odontol.

Porto Alegre
V. 32

N. 1

p.24-24

JULHO 